\title{
PENERAPAN MODEL PEMBELAJARAN STUDENT FACILITATOR AND EXPLAINING UNTUK MENINGKATKAN AKTIVITAS BELAJAR DAN PEMAHAMAN KONSEP MATEMATIKA SISWA KELAS VIII A3 SMP NEGERI 3 SAWAN
}

\author{
N. M. Suastini, I. N. Suparta, I. G. N. Yudi. Hartawan \\ Jurusan Pendidikan Matematika, Universitas Pendidikan Ganesha \\ Singaraja, Indonesia \\ e-mail: suastinitini@gmail.com, isuparta@yahoo.com, hartawan.math@gmail.com
}

\begin{abstract}
Abstrak
Penelitian ini bertujuan untuk mendeskripsikan hasil penerapan model pembelajaran Student Facilitator and Explaining terhadap aktivitas belajar dan pemahaman konsep matematika siswa. Penelitian ini merupakan penelitian tindakan kelas yang dilaksanakan dalam tiga siklus. Subjek penelitian adalah siswa kelas VIII A3 SMP Negeri 3 Sawan yang berjumlah 28 orang. Metode pengumpulan data yang digunakan yaitu observasi, tes, dan penyebaran angket. Data yang diperoleh dianalisis secara deskriptif. Hasil penelitian menunjukkan bahwa aktivitas belajar matematika siswa meningkat pada setiap siklusnya. Pada siklus I, siswa yang berada pada kriteria kurang aktif sebanyak 1 orang, kriteria cukup aktif sebanyak 26 orang, dan kriteria aktif sebanyak 1 orang. Pada sikus II, siswa yang berada pada kriteria cukup aktif sebanyak 17 orang dan kriteria aktif sebanyak 11 orang. Pada siklus III, siswa yang berada pada kriteria aktif sebanyak 26 orang dan kriteria sangat aktif sebanyak 2 orang. Peningkatan rata-rata nilai pemahaman konsep matematika siswa dari tahun-tahun sebelumnya yaitu dari 65,48 menjadi 75,55 pada siklus I, dari 53,74 menjadi 75,83 pada siklus II, dan dari 53,74 menjadi 78,43 pada siklus III. Peningkatan tersebut dapat tercapai karena siswa berperan sebagai fasilitator, memfasilitasi siswa lain dalam kegiatan pembelajaran sehingga melatih keaktifan siswa untuk berusaha memahami suatu materi, meningkatkan kemampuan saling bertukar pendapat, dan keberanian mengutarakan pendapat secara tebuka yang menyebabkan terjadinya interaksi, baik antara siswa dengan siswa maupun antara siswa dengan guru. Skor tanggapan seetiap siswa terhadap model pembelajaran yang diterapkan berada pada kriteria positif.
\end{abstract}

Kata kunci: Student Facilitator and Explaining, aktivitas belajar, pemahaman konsep matematika, tanggapan siswa.

\begin{abstract}
This research aimed to describe the implementation of Student Facilitator and Explaining model in increasing students' learning activity and students' mathematics concept understanding. This research is classroom action research which was done in three cycles. The subjects of this research were students VIII A3 class in SMP Negeri 3 Sawan which consisted of 28 students. The methods for collecting the research data were observation, test, and questionnaire. The collected data were analyzed descriptively. The result of this research showed that the students' learning activity increased in every cycle. In first cycle, we found that 1 student was in the less active criteria, 26 students were in the quite active criteria, and 1 student was in the active criteria. In second cycle, we found that 17 students were in the quite active criteria and 11 students were in the active criteria. In third cycle, we found that 26 students were in the active criteria and 2 students were in the very active criteria. The increase of students' mathematics concept understanding from the previous years is from 65.48 to 75.55 in first cycle, from 53.74 to 75.83 in second cycle, and from 53.74 to 78.43 in third cycle. The increase can be achieved because students act as facilitators to facilitate other students in learning activities, so it trained the students' activeness to understand a concept, improve the ability to exchange opinions and the courage to express opinions. These
\end{abstract}


activities lead to interaction that happened between students with students and students with teacher. The score of each student's response toward the implementation of learning model in the positive criteria.

Keywords : Student Facilitator and Explaining, learning activity, mathematics concept understanding, students'response.

\section{PENDAHULUAN}

Pendidikan mempunyai peranan penting dalam mewujudkan manusia yang seutuhnya. Tujuan pendidikan tidak terlepas dari peningkatan sumber daya manusia. Meningkatkan sumber daya manusia dapat dilakukan melalui suatu proses pembelajaran. Inti dari proses pembelajaran adalah kegiatan belajar siswa dalam mencapai tujuan pembelajaran. Tujuan pembelajaran akan dapat dicapai jika siswa berusaha secara aktif untuk mencapainya.

Salah satu pembelajaran yang memiliki peranan penting dalam pendidikan adalah pembelajaran matematika. Hal ini dapat dilihat dari alokasi waktu, jam pelajaran matematika di sekolah lebih banyak dibandingkan jam pelajaran lain. Mata pelajaran matematika diberikan pada semua jenjang pendidikan, mulai dari pendidikan dasar sampai perguruan tinggi.

Matematika bukanlah ilmu yang sekedar menghitung saja, tetapi juga menuntut siswa dalam memahami konsep matematika. Hudojo (2015) menyatakan bahwa belajar matematika berarti belajar tentang konsep-konsep yang terdapat dalam bahasan yang dipelajari serta mencari hubungan-hubungan antara konsep-konsep tersebut. Hubungan antara konsep-konsep tersebut dapat dicari setelah memahami konsep-konsep matematika. Dengan demikian, konsep-konsep pada matematika perlu dikuasai dengan baik oleh siswa. Pemahaman konsep yang baik dan keterampilan dalam menggunakan konsep akan membantu siswa dalam memecahkan suatu masalah matematika.

Berdasarkan hasil observasi dan wawancara dengan guru mata pelajaran matematika di kelas VIII A3 pada tanggal 18 Januari 2017 diperoleh informasi bahwa siswa masih kesulitan dalam memahami materi yang diberikan. Rendahnya pemahaman konsep matematika siswa kelas VIII A3 dapat dilihat dari rata-rata nilai ulangan harian siswa untuk beberapa materi pada dua tahun terakhir yang disajikan pada Tabel 1.

Tabel 1. Rata-Rata Nilai Ulangan Harian Matematika Siswa Kelas VIII B6

\begin{tabular}{cccccc}
\hline No. & Tahun & \multicolumn{2}{c}{ Kubus dan Balok } & \multicolumn{2}{c}{ Prisma dan Limas } \\
& Pelajaran & Rata-Rata & Ketuntasan Belajar & Rata-Rata & Ketuntasan Belajar \\
\hline 1. & $2014 / 2015$ & 65,71 & $51,85 \%$ & 57,14 & $37,04 \%$ \\
2. & $2015 / 2016$ & 65,25 & $53,57 \%$ & 50,35 & $46,43 \%$ \\
& Rata-Rata & $\mathbf{6 5 , 4 8}$ & $\mathbf{5 2 , 7 1 \%}$ & $\mathbf{5 3 , 7 4}$ & $\mathbf{4 1 , 7 4 \%}$ \\
\hline & & & \multicolumn{3}{c}{ (Arsip SMP Negeri 3 Sawan) }
\end{tabular}

Di samping itu, hasil wawancara dan observasi yang diperoleh adalah sebagai berikut.

1. Proses pembelajaran dominan berpusat pada guru, guru lebih banyak menyampaikan materi kepada siswa sehingga siswa belum terbiasa berdiskusi dalam kelompok.

2. Banyak siswa yang mengalami kesalahan menjawab soal dengan jenis memilih contoh dan bukan contoh, serta siswa belum bisa memberikan alasan dari jawaban yang ia pilih pada saat ulangan harian.

3. Siswa mengalami kesulitan ketika diberikan soal yang sedikit berbeda dengan contoh yang telah diberikan. Hal ini disebabkan karena siswa kurang terlatih untuk mengulang langkah-langkah penyelesaian dengan menggunakan konsep yang menjadi kegiatan pokok dalam pembelajaran matematika.

4. Aktivitas yang dilakukan siswa selama kegiatan pembelajaran masih rendah. 
Hal ini dapat dilihat pada awal pembelajaran siswa kurang siap mengikuti pembelajaran karena banyak siswa yang tidak aktif merespon yang disampaikan oleh guru. Terlihat bahwa siswa kurang membaca materi yang akan dipelajari terlebih dahulu di rumah sebelum dipelajari di sekolah. Selain itu, siswa masih enggan untuk menanyakan permasalahan yang tidak dipahami kepada guru. Pada akhir pembelajaran, siswa masih kurang aktif ketika guru meminta siswa untuk menyampaikan kesimpulan dari materi yang telah dipelajari. Hal ini menyebabkan guru kesulitan untuk mengetahui kemampuan siswa dalam menerima keseluruhan informasi yang diberikan ataupun yang diperoleh pada proses pembelajaran. Siswa yang belum memahami konsep akan tenggelam dalam ketidaktahuannya dan akan mengakibatkan rendahnya pemahaman konsep matematika siswa.

5. Rasa tanggung jawab dan keseriusan siswa dalam mengerjakan soal masih rendah karena masih terdapat beberapa siswa yang mendiskusikan hal-hal yang tidak terkait dengan permasalahan yang diberikan, mereka menggantungkan hasil pekerjaan pada siswa yang dianggap lebih pintar sehingga siswa cenderung pasif dan menunggu jawaban siswa lainnya.

Berdasarkan beberapa permasalahan yang telah disampaikan, diperlukan suatu solusi yang dapat meningkatkan kemampuan aktivitas belajar dan pemahaman konsep matematika siswa. Upaya yang dapat dilakukan untuk menyikapi beberapa permasalahan tersebut yaitu melalui penerapan model pembelajaran yang kreatif dan inovatif. Salah satu model pembelajaran yang dapat digunakan untuk meningkatkan aktivitas belajar dan pemahaman konsep matematika siswa kelas VIII A3 SMP Negeri 3 Sawan adalah model pembelajaran Student Facilitator and Explaining.

Sukma (2015) menyatakan bahwa pemahaman konsep matematika siswa yang dibelajarkan dengan model pembelajaran Student Facilitator and Explaining lebih baik daripada siswa yang dibelajarkan dengan model pembelajaran konvensional. Menurut Darwis, dkk (2004), model pembelajaran Student Facilitator and Explaining adalah salah satu tipe model pembelajaran kooperatif yang menekankan pada struktur khusus yang dirancang untuk mempengaruhi pola interaksi dan memiliki tujuan untuk meningkatkan penguasaan akademik. Model pembelajaran ini melibatkan siswa secara aktif dalam proses pembelajaran. Kurniasih (2015) menyatakan bahwa model pembelajaran Student Facilitator and Explaining merupakan model pembelajaran yang melatih siswa untuk mempresentasikan ide atau gagasan mereka pada temantemannya. Siswa berperan untuk memfasilitasi siswa lainnya dalam kegiatan pembelajaran.

Menurut Kurniasih (2015), model pembelajaran Student Facilitator and Explaining memiliki 6 tahapan, yaitu (1) siswa menyimak kompetensi yang ingin dicapai dalam pembelajaran tersebut, (2) siswa menyimak garis-garis besar materi pembelajaran, (3) siswa menjelaskan/ mendemonstrasikan materi kepada siswa lainnya, misalnya melalui bagan atau peta konsep secara bergiliran, (4) siswa mengamati poin-poin penting dari materi yang telah dijelaskan, (5) siswa mengulas kembali materi dari awal pembelajaran, (6) Penutup.

Berdasarkan pemaparan di atas, penulis termotivasi untuk melakukan penelitian yang berjudul "Penerapan Model Pembelajaran Student Facilitator and Explaining untuk Meningkatkan Aktivitas Belajar dan Pemahaman Konsep Matematika Siswa Kelas VIII A3 SMP Negeri 3 Sawan".

\section{METODE}

Penelitian ini termasuk dalam jenis penelitian tindakan kelas yang bertujuan untuk meningkatkan aktivitas belajar dan pemahaman konsep matematika siswa kelas VIII A3 SMP Negeri 3 Sawan. Penelitian ini berjalan dalam tiga siklus, setiap siklus terdiri dari empat tahapan yaitu perencanaan tindakan, pelaksanaan tindakan, observasi dan evaluasi, serta refleksi. Penelitian ini bersifat kolaboratif yaitu bentuk kerjasama antara peneliti dengan guru sebagai praktisi sehingga memungkinkan terjadinya 
pemahaman dan kesepakatan terhadap suatu masalah yang dihadapi.

Subjek dalam penelitian ini adalah semua siswa kelas VIII A3 SMP Negeri 3 Sawan Semester Genap Tahun Ajaran 2016/2017 dengan jumlah 28 orang siswa yang terdiri dari 14 orang siswa laki-laki dan 14 orang siswa perempuan.

Objek yang diteliti dalam penelitian ini adalah aktivitas belajar dan pemahaman konsep matematika siswa kelas VIII A3 SMP Negeri 3 Sawan Semester Genap Tahun Ajaran 2016/2017 terhadap model pembelajaran Student Facilitator and Explaining.

Prosedur dalam penelitian ini dibagi menjadi dua tahap kegiatan, yaitu refleksi awal dan pelaksanaan penelitian yang berlangsung dalam tiga siklus. Setiap siklus dilaksanakan selama empat kali pertemuan yang terdiri atas tiga kali pertemuan untuk pelaksanaan tindakan dan satu kali pertemuan untuk melakukan tes pemahaman konsep.

Instrumen dalam penelitian ini berupa lembar observasi aktivitas belajar, tes pemahaman konsep matematika, dan angket tanggapan. Lembar observasi digunakan untuk mendapatkan data mengenai aktivitas belajar siswa yang dilakukan pada setiap pertemuan pelaksanaan proses pembelajaran. Tes pemahaman konsep matematika berupa tes uraian digunakan untuk mengumpulkan data pemahaman konsep matematika siswa. Angket digunakan untuk mengumpulkan data mengenai tanggapan siswa terhadap penerapan model pembelajaran Student Facilitator and Explaining.

Data aktivitas belajar siswa diperoleh melalui observasi pada setiap kegiatan pembelajaran, data pemahaman konsep matematika siswa diperoleh melalui tes pemahaman konsep matematika yang dilakukan pada tahap evaluasi di setiap akhir siklus, dan data tanggapan siswa terhadap penerapan model pembelajaran Student Facilitator and Explaining dikumpulkan melalui angket tanggapan siswa yang terdiri dari 15 butir pernyataan yang diberikan pada akhir siklus II dan siklus III.

Setelah data aktivitas belajar, pemahaman konsep matematika siswa, dan data tanggapan siswa terhadap penerapan model pembelajaran Student Facilitator and Explaining terkumpul, selanjutnya data tersebut dianalisis secara deskriptif, yaitu dengan menganalisis aktivitas belajar siswa yang ditinjau dari rata-rata aktivitas belajar siswa, pemahaman konsep matematika siswa yang ditinjau dari rata-rata nilai pemahaman konsep matematika siswa, dan rata-rata skor tanggapan siswa untuk data tanggapan siswa terhadap model pembelajaran yang diterapkan.

Analisis data aktivitas belajar siswa dilakukan dengan menghitung rata-rata nilai aktivtas belajar siswa $(A)$ dengan rumus:

$\bar{A}=\frac{\sum_{i=1}^{n} A_{i}}{n}$

Keterangan:

$\bar{A}=$ rata-rata aktivitas belajar siswa

$A_{i}=$ aktivitas belajar siswa ke- $i$

$n=$ banyak siswa

Kriteria yang digunakan dalam penggolongan aktivitas belajar siswa disajikan pada Tabel 2.

Tabel 2. Kriteria Penggolongan Aktivitas Belajar Siswa

\begin{tabular}{ccc}
\hline No. & Rentang Nilai & Kriteria \\
\hline 1 & $\mathrm{~A} \geq 80$ & Sangat Aktif \\
2 & $60 \leq A<80$ & Aktif \\
3 & $40 \leq A<60$ & Cukup Aktif \\
4 & $20 \leq A<40$ & Kurang Aktif \\
5 & $A<20$ & Sangat Kurang Aktif \\
\hline
\end{tabular}

Analisis data pemahaman konsep matematika siswa dilakukan dengan menghitung rata-rata nilai pemahaman konsep matematika siswa $(X)$ dengan rumus: 
$\bar{X}=\frac{\sum_{i=1}^{n} X_{i}}{n}$

Keterangan:

$\bar{X}=$ rata-rata nilai pemahaman konsep matematika siswa

$X_{i}=$ nilai pemahaman konsep matematika siswa ke-i

$n$ = banyak siswa
Selanjutnya data pemahaman konsep matematika siswa dikualifikasikan berdasarkan Kriteria Ketuntasan Minimal (KKM) mata pelajaran matematika kelas VIII A3 SMP Negeri 3 Sawan yang disajikan pada Tabel 3.

Tabel 3. Kriteria Ketuntasan Belajar Siswa

\begin{tabular}{ccc}
\hline No. & Rentang Nilai & Kategori \\
\hline 1 & $75 \leq \bar{X} \leq 100$ & Tuntas \\
2 & $0 \leq \bar{X}<75$ & Belum Tuntas \\
\hline
\end{tabular}

Analisis data tanggapan siswa Keterangan:

dilakukan dengan menghitung skor $\bar{T}=$ rata-rata nilai aktivitas belajar siswa

tanggapan siswa $(T)$ dengan rumus: $\quad T_{i}=$ nilai aktivitas belajar siswa ke-i

$\bar{T}=\frac{\sum_{i=1}^{n} T_{i}}{n}$

$n=$ banyak siswa

Kriteria yang digunakan dalam penggolongan tanggapan siswa disajikan pada Tabel 4.

Tabel 4. Kriteria Penggolongan Skor Tanggapan Siswa

\begin{tabular}{ccc}
\hline No. & Rentang Nilai & Kategori \\
\hline 1 & $\bar{T} \geq 63$ & Sangat Positif \\
2 & $51 \leq \bar{T}<63$ & Positif \\
3 & $39 \leq \bar{T}<51$ & Cukup Positif \\
4 & $27 \leq \bar{T}<39$ & Negatif \\
5 & $\bar{T}<27$ & Sangat Negatif \\
\hline
\end{tabular}

Berdasarkan analisis data tersebut, penerapan model pembelajaran Student Facilitator and Explaining dikatakan berhasil apabila telah memenuhi indikator keberhasilan, yaitu (1) nilai aktivitas belajar siswa mengalami peningkatan dari setiap siklusnya dan minimal mencapai kriteria aktif. (2) rata-rata nilai pemahaman konsep matematika siswa setiap siklus secara klasikal minimal 75 dengan persentase ketuntasan belajar secara klasikal minimal $65 \%$ pada siklus I, $70 \%$ pada siklus II, dan
$75 \%$ pada siklus III. (3) skor tanggapan siswa terhadap pembelajaran matematika setelah diterapkan model pembelajaran Student Facilitator and Explaining minimal mencapai kriteria positif.

\section{HASIL DAN PEMBAHASAN}

Berdasarkan hasil penelitian yang sudah dilaksanakan, rata-rata aktivitas belajar siswa kelas VIII A3 SMP Negeri 3 Sawan pada siklus I, siklus II dan siklus III terlihat pada Tabel 5 berikut. 
Tabel 5. Hasil Analisis Data Aktivitas Belajar Siswa

\begin{tabular}{ccc}
\hline Tahapan & Rata-Rata & Kriteria \\
\hline Siklus I & 48,21 & Cukup Aktif \\
Siklus II & 59,92 & Cukup Aktif \\
Siklus III & 72,75 & Aktif \\
\hline
\end{tabular}

Pada Tabel 5 terlihat bahwa aktivitas belajar siswa secara klasikal pada siklus I ke siklus II mengalami peningkatan sebesar 11,71 yaitu dari 49,21 menjadi 59,92, kemudian dari siklus II ke siklus III mengalami peningkatan sebesar 12,83 yaitu dari 59,92 menjadi 72,75 . Selain secara klasikal, aktivitas belajar siswa juga mengalami peningkatan pada setiap siklusnya. Pada siklus I, siswa yang aktivitas belajarnya berada pada kriteria kurang aktif sebanyak 1 orang, kriteria cukup aktif sebanyak 26 orang, dan kriteria aktif sebanyak 1 orang. Pada sikus II, siswa yang aktivitas belajarnya berada pada kriteria cukup aktif sebanyak 17 orang dan kriteria aktif sebanyak 11 orang. Pada siklus III, siswa yang aktivitas belajarnya berada pada kriteria aktif sebanyak 26 orang dan kriteria sangat aktif sebanyak 2 orang. Berdasarkan analisis data tersebut, dapat disimpulkan bahwa aktivitas belajar siswa kelas VIII A3 SMP Negeri 3 Sawan sudah memenuhi indikator keberhasilan.

Rata-rata nilai pemahaman konsep matematika siswa kelas VIII A3 SMP Negeri 3 Sawan pada siklus I, siklus II dan siklus III terlihat pada Tabel 6 berikut.

Tabel 6. Hasil Analisis Data Pemahaman Konsep Matematika Siswa

\begin{tabular}{ccc}
\hline Tahapan & $\begin{array}{c}\text { Rata-Rata Nilai Th. 2014/2015 } \\
\text { dan 2015/2016 }\end{array}$ & $\begin{array}{c}\text { Setelah Pemberian } \\
\text { Tindakan }\end{array}$ \\
\hline Siklus I & 65,46 & 75,55 \\
Siklus II & 53,74 & 75,82 \\
Siklus III & 53,74 & 78,43 \\
\hline
\end{tabular}

Selain itu, data persentase ketuntasan belajar secara klasikal terlihat

pada Tabel 7 berikut.

Tabel 7. Hasil Analisis Data Ketuntasan Belajar Siswa secara Klasikal

\begin{tabular}{cccc}
\hline Tahapan & Tahun 2014/2015 & Tahun2015/2016 & $\begin{array}{c}\text { Setelah Pemberian } \\
\text { Tindakan }\end{array}$ \\
\hline Siklus I & $51,85 \%$ & $53,57 \%$ & $67,86 \%$ \\
Siklus II & $37,04 \%$ & $46,43 \%$ & $71,43 \%$ \\
Siklus III & $37,04 \%$ & $46,43 \%$ & $75 \%$ \\
\hline
\end{tabular}

Pemahaman konsep matematika siswa yang diperoleh dari hasil penelitian yaitu rata-rata nilai pemahaman konsep matematika secara klasikal dan persentase ketuntasan belajar secara klasikal mengalami peningkatan dari tahun-tahun sebelumnya pada masing-masing siklus. Pada siklus I dari 65,48 menjadi 75,55 dengan ketuntasan belajar dari $51,85 \%$ (tahun ajaran 2014/2015) dan 53,57\% (tahun ajaran 2015/2016) menjadi 67,86\%. Pada siklus II dari 53,74 menjadi 75,82 dengan ketuntasan belajar dari $37,04 \%$ (tahun ajaran 2014/2015) dan 46,43\% (tahun ajaran 2015/2016) menjadi $71,43 \%$.
Pada siklus III dari 53,74 menjadi 78,43 dengan ketuntasan belajar dari $37,04 \%$ (tahun ajaran 2014/2015) dan 46,43\% (tahun ajaran 2015/2016) menjadi 75\%. Berdasarkan analisis data tersebut, dapat disimpulkan bahwa rata-rata nilai pemahaman konsep matematika siswa kelas VIII A3 SMP Negeri 3 Sawan sudah memenuhi indikator keberhasilan.

Berdasarkan analisis data yang telah dilakukan, diperoleh rata-rata skor tanggapan siswa terhadap model pembelajaran Student Facilitator and Explaining secara klasikal pada akhir siklus II sebesar 55,96 dan tidak jauh berbeda 
dengan rata-rata skor pada akhir siklus III yaitu 58,18 . Pada akhir siklus II, siswa yang memberikan tanggapan positif sebanyak 24 orang dan tanggapan sangat positif sebanyak 4 orang sedangkan pada akhir sikus III siswa yang memberikan tanggapan positif sebanyak 21 orang dan yang memberikan tanggapan sangat positif sebanyak 7 orang. Jadi, dapat disimpulkan bahwa tanggapan siswa terhadap penerapan model pembelajaran Student Fasilitator and Explaining sudah memenuhi indikator keberhasilan yang ditetapkan yaitu skor masing-masing siswa mencapai kriteria positif.

Berdasarkan hasil refleksi awal penelitian ini maka dilakukan tindakan dengan menerapkan model pembelajaran Student Fasilitator and Explaining. Setelah pelaksanaan siklus I, dapat disimpulkan bahwa pelaksanaan tindakan pada siklus I belum memenuhi indikator keberhasilan aktivitas belajar karena belum semua siswa berada pada kriteria aktif, dan sudah memenuhi indikator pemahaman konsep matematika yaitu rata-rata nilai pemahaman konsep matematika siswa secara klasikal minimal 75 dengan ketuntasan belajar minimal $65 \%$.

Setelah melakukan kegiatan observasi dan evaluasi, pada siklus I juga dilakukan refleksi terhadap pelaksanaan pembelajaran yang telah berlangsung selama siklus I. Berdasarkan hasil refleksi siklus I, pelaksanaan pembelajaran dengan penerapan model pembelajaran Student Facilitator and Explaining memiliki beberapa permasalahan yaitu (1) siswa masih bingung menyajikan materi dalam bentuk peta konsep, (2) saat melakukan diskusi kelompok, tidak semua siswa aktif mengerjakan LKS yang diberikan, beberapa siswa enggan mengungkapkan pendapat atau malu bertanya dengan teman kelompoknya atau siswa yang bertindak sebagai fasilitator, (3) pada tahap menjelaskan/mendemonstrasikan materi di depan kelas melalui peta konsep yang telah dibuat terlihat belum adanya keberanian siswa untuk mengacungkan tangan, (4) terdapat siswa yang membuat penyelesaian soal tidak sesuai dengan indikator pemahaman konsep yang diberikan, salah satu kasus yang ditemukan yaitu siswa belum terbiasa menuliskan konsep yang digunakan terlebih dahulu dalam menyelesaikan soal, (5) pada tahap siswa mengulas kembali materi dari awal pembelajaran, guru memberikan kesempatan kepada siswa untuk menanyakan materi yang belum dipahami, tetapi siswa tidak aktif untuk bertanya, (6) siswa belum terbiasa untuk membuat kesimpulan dari materi yang telah dipelajari di akhir pembelajaran, hal ini dapat dilihat dari data hasil observasi yang menunjukkan rendahnya aktivitas siswa pada deskriptor siswa membuat kesimpulan dalam kelompoknya dan mengacungkan tangan untuk menyampaikan kesimpulan.

Berdasarkan

permasalahanpermasalahan yang dihadapi pada siklus I, peneliti berdiskusi dengan guru sehingga disepakati beberapa solusi untuk mengatasi permasalahan-permasalahan tersebut. Hal ini digunakan sebagai pertimbangan dalam melaksanakan perencanaan yang lebih baik pada siklus II. Adapun beberapa solusi tersebut yaitu (1) mengarahkan siswa menyajikan materi dalam bentuk peta konsep dengan menuliskan kata-kata kunci dari materi yang perlu ditulis dalam peta konsep, apabila nanti siswa sudah terbiasa, guru akan membiarkan siswa secara mandiri menyajikan materi dalam bentuk peta konsep sesuai dengan kreasinya, (2) memberikan motivasi kepada siswa agar mengerjakan LKS dengan baik dan menyampaikan bahwa akan menunjuk siswa secara acak dalam pembahasan LKS, (3) menekankan kembali kepada siswa agar tidak takut dalam menyampaikan hasil diskusi kelompok dan jangan ragu menyampaikan pendapat karena keaktifan di kelas tetap dinilai, serta memberikan penguatan positif kepada siswa yang sudah berusaha mengemukakan pendapat, (4) menghimbau kepada siswa untuk berusaha mengingat konsep-konsep penting dari materi yang telah dipelajari dan lebih menekankan siswa agar dalam menyelesaikan soal menggunakan indikator pemahaman konsep seperti yang pernah dicontohkan, (5) memberikan kesempatan lebih banyak kepada siswa untuk menanyakan hal-hal yang belum dipahami dengan pertanyaan pancingan untuk 
mengetahui tingkat pemahaman siswa terhadap materi yang telah dipelajari.

Berdasarkan hasil refleksi siklus I maka dilakukan beberapa tindakan agar pembelajaran pada siklus II menjadi lebih baik. Tindakan yang dilakukan oleh guru untuk memperbaiki pelaksanaan siklus I telah berjalan sesuai dengan perencanaan tindakan pada siklus II. Setelah pelakasanaan siklus II diperoleh kesimpulan bahwa pelaksanaan tindakan pada siklus II belum memenuhi indikator keberhasilan aktivitas belajar karena belum semua siswa berada pada kriteria aktif dan sudah memenuhi indikator pemahaman konsep matematika yaitu rata-rata nilai pemahaman konsep matematika siswa secara klasikal minimal 75 dengan ketuntasan belajar minimal $70 \%$.

$$
\text { Setelah melakukan kegiatan }
$$

observasi dan evaluasi, pada siklus II juga dilakukan refleksi terhadap pelaksanaan pembelajaran yang telah berlangsung selama siklus II. Secara umum, kegiatan pembelajaran pada siklus II telah berjalan dengan baik dan telah tampak adanya peningkatan dari siklus I, baik dari segi proses pembelajaran maupun dari hasil tindakan. Pada tahap pembelajaran siklus II siswa terlihat sudah mulai terbiasa menyajikan materi dalam bentuk peta konsep. Guru telah berupaya membuat siswa untuk lebih aktif dalam berdiskusi dan siswa tampak lebih tertib dan aktif dibandingkan pada siklus I. Siswa sudah mulai berani menyampaikan pendapat dan menyampaikan kesimpulan dari materi yang telah dipelajari, terlihat adanya peningkatan aktivitas belajar pada beberapa desktiptor yaitu pada deskriptor siswa membuat kesimpulan dalam kelompoknya dan deskriptor siswa mengacungkan tangan untuk menyampaikan kesimpulan.

Peneliti bersama guru kembali mengkaji beberapa kekurangan terkait dengan pelaksanaan tindakan serta upaya yang telah dilakukan untuk mengatasi beberapa kekurangan tersebut sebagai pertimbangan dalam melaksanakan perencanaan yang lebih baik pada siklus III. Adapun beberapa kekurangan yang masih ditemukan pada siklus II yaitu (1) saat pemberian apersepsi, sebagian siswa lupa dengan materi pada pertemuan sebelumnya, (2) beberapa siswa tidak bersungguh-sungguh selama kegiatan diskusi kelompok berlangsung, terdapat beberapa siswa yang hanya menyalin pekerjaan temannya tanpa ikut berpartisipasi menyelesaikan permasalahan yang diberikan, (3) pada tahap menjelaskan/mendemonstrasikan materi di depan kelas melalui peta konsep yang telah dibuat, tampak belum semua siswa berani mengacungkan tangan untuk menyampaikan materi, (4) ketika memiliki pendapat yang berbeda dengan temannya, siswa cenderung malu ketika diminta untuk menyapaikan di depan kelas.

$$
\text { Dalam tahap perencanaan }
$$

pembelajaran untuk siklus III, peneliti bersama guru kembali menentukan upaya perbaikan untuk mengatasi permasalahanpermasalahan yang ditemui selama pelaksanaan pembelajaran siklus II. Adapun upaya perbaikan yang dilakukan dalam pembelajaran untuk siklus III yaitu (1) menekankan kembali kepada siswa untuk mencatat kesimpulan dan menambahkan peta konsep yang kurang lengkap, guru memberikan tugas berupa soal yang berkaitan dengan konsep tersebut yang akan dikumpulkan pada pertemuan selanjutnya, (2) memberikan perhatian lebih kepada siswa yang kurang bersunguh-sungguh selama kegiatan diskusi kelompok berlangsung, serta memotivasi siswa untuk bertanya dan berdiskusi dengan teman satu kelompoknya sehingga masalah yang diberikan di dalam LKS dapat diselesaikan secara bersamasama, (3) memotivasi siswa agar tidak malu dan tidak takut mencoba, serta belajar menyampaikan pendapat di depan kelas, memberikan penguatan positif seperti memberikan pujian kepada siswa yang sudah berani menjelaskan di depan kelas walaupun jawabannya belum sepenuhnya benar dan menetapkan kelompok terbaik untuk kelompok yang paling aktif dalam kegiatan pembelajaran, (4) memberikan pernyataan pancingan kepada siswa bahwa pendapat yang disampaikan siswa sebelumnya belum tentu benar sehingga siswa lebih percaya diri menyampaikan pendapatnya di depan kelas, pendapat siswa yang berbeda dibandingkan 
kemudian diberikan konfirmasi letak kesalahan yang dilakukan siswa, dan siswa yang menyampaikan pendapat dengan benar ataupun salah tetap diberikan penguatan positif agar selalu aktif menyampaikan pendapat.

Berdasarkan hasil refleksi siklus II maka dilakukan beberapa tindakan agar pembelajaran pada siklus III menjadi lebih baik. Tindakan yang dilakukan oleh guru untuk memperbaiki pelaksanaan siklus II telah berjalan sesuai dengan perencanaan tindakan pada siklus III. Setelah pelakasanaan siklus III diperoleh kesimpulan bahwa pelaksanaan tindakan pada siklus III sudah memenuhi indikator keberhasilan aktivitas belajar karena semua siswa sudah berada pada kriteria aktif dan sudah memenuhi indikator pemahaman konsep matematika yaitu rata-rata nilai pemahaman konsep matematika siswa secara klasikal minimal 75 dengan ketuntasan belajar secara klasikal minimal $75 \%$.

Berdasarkan penyempurnaan tindakan yang dilakukan pada refleksi siklus II terlihat bahwa pembelajaran pada siklus III mengalami peningkatan, baik dari segi hasil maupun proses. Adapun temuantemuan selama pelaksanaan tindakan siklus III yaitu (1) secara umum proses pembelajaran telah berjalan sesuai dengan Rencana Pelaksanaan Pembelajaran (RPP) yang dibuat, (2) kondisi pembelajaran tampak lebih kondusif, siswa tampak antusias mengikuti pembelajaran dan sudah berusaha untuk mengerjakan tugas yang diberikan, sudah banyak siswa yang berani menyampaikan pendapat dan menjawab pertanyaan guru ketika kegiatan apersepsi pada awal pembelajaran, (3) siswa sudah menunjukkan sikap yang positif dalam memecahkan permasalahan di dalam kelompoknya. Hal ini terlihat dari masing-masing anggota kelompok yang ikut berpartisipasi dalam memecahkan masalah yang diberikan dan mau menanyakan halhal yang belum dipahami kepada anggota lain yang sudah paham, (4) pada tahap menjelaskan/mendemonstrasikan materi di depan kelas melalui peta konsep yang telah dibuat, siswa tampak antusias dan sebagian besar sudah berani mengacungkan tangan untuk menyampaikan materi.

Berdasarkan temuan-temuan yang telah disampaikan, dapat dikatakan bahwa pada siklus III tidak terdapat lagi permasalahan yang sangat berarti dalam proses pembelajaran.

\section{PEMBAHASAN}

Peningkatan aktivitas belajar siswa setelah pemberian tindakan disebabkan karena (1) siswa membuat peta konsep terlebih dahulu sebelum materi pelajaran disampaikan di sekolah. Kegiatan ini menuntut siswa untuk membaca materi pelajaran terlebih dahulu sehingga siswa terlihat siap untuk melaksanakan pembelajaran di sekolah. Kesiapan siswa pada saat pembelajaran mampu meningkatkan interaksi baik antara siswa dengan siswa lainnya maupun siswa dengan guru, seperti siswa mampu merespon pertanyaan-pertanyaan dari guru, mampu menjelaskan suatu konsep di depan kelas, bertanya mengenai hal-hal yang belum dipahami yang ditemukan ketika membuat peta konsep, dan mampu menjelaskan suatu konsep di depan kelas. Hal ini sesuai dengan teori Piaget yang menyatakan bahwa ketika seseorang telah memiliki kesiapan belajar dalam dirinya maka siswa tersebut sudah siap untuk merespon dan memberikan reaksi ketika kegiatan belajar berlangsung. Dengan demikian, indikator interaksi antara siswa dengan siswa lainnya dan interaksi antara siswa dengan guru dapat tercapai, (2) siswa mengulas kembali materi dari awal pembelajaran yang memberikan kesempatan kepada siswa untuk menanyakan hal-hal yang belum dipahami. Brooks \& Brooks (dalam Johnson, 2002) menyatakan bahwa untuk bisa mengerti, siswa harus punya kesempatan untuk membentuk dan mengajukan pertanyaan. Guru membantu siswa agar tidak takut bertanya maupun menyampaikan pendapat, misalnya dengan memberikan pertanyaan pancingan sehingga siswa berinteraksi secara aktif dengan guru. Dengan demikian, indikator aktivitas belajar terkait interaksi antara siswa dengan guru dapat tercapai, (3) siswa berperan sebagai fasilitator dalam masing-masing 
kelompoknya membantu anggota kelompok memahami materi pelajaran dan permasalahan pada LKS. Siswa yang malu bertanya kepada guru akan bertanya kepada siswa lainnya, sedangkan siswa yang ditanyakan akan berusaha menjawab pertanyaan temannya. Astuti (2013) dalam penelitiannya menyatakan bahwa siswa lebih mudah menyerap materi pelajaran melalui penjelasan siswa yang lainnya. Kegiatan ini membuat siswa saling menukarkan informasi, baik dalam kelompok maupun di luar kelompok dalam memahami materi pelajaran sehingga siswa yang sudah memahami materi pelajaran ikut aktif mencari solusi dari permasalahan yang diberikan. Dengan demikian, indikator aktivitas siswa dalam melakasanakan pembelajaran, interaksi antara siswa dengan siswa lainnya, dan kerjasama kelompok dapat tercapai, (4) siswa menyampaikan hasil diskusi kelompoknya melalui peta konsep yang telah dibuat. Hasil diskusi kelompok disampaikan secara bergiliran sehingga mendorong siswa untuk berdiskusi dengan baik dan antusias dalam mengikuti pelajaran. Siswa melakukan berbagai upaya agar memahami konsepkonsep yang sedang dipelajari, seperti bertanya kepada siswa yang sudah paham terhadap konsep-konsep yang menyebabkan siswa berinteraksi secara aktif dengan siswa lainnya. Dengan demikian, indikator aktivitas siswa dalam melaksanakan pembelajaran, antusiame siswa dalam mengikuti pelajaran, dan interaksi antara siswa dengan siswa lainnya dapat tercapai, (5) siswa mencatat poinpoin penting dari materi yang sedang dipelajari. Kegiatan ini membantu siswa dalam membuat kesimpulan dari keseluruhan materi yang telah dipelajari pada suatu pertemuan di dalam kelompoknya karena siswa sudah mengetahui poin penting dari materi pelajaran tersebut. Siswa yang sudah mampu membuat kesimpulan di dalam kelompoknya merasa percaya diri untuk mengacungkan tangan dalam menyampaikan kesimpulan. Kesimpulan yang disampaikan siswa kemudian dikonfirmasi oleh guru, sedangkan siswa lainnya selalu mencatat kesimpulan yang telah disampaikan karena pada kegiatan apersepsi di pertemuan selanjutnya guru akan menanyakan materi tersebut. Dengan demikian, indikator partisipasi siswa dalam menyimpulkan materi pelajaran dapat tercapai.

Adapun yang mengakibatkan meningkatnya pemahaman konsep matematika siswa yaitu (1) siswa membuat peta konsep terlebih dahulu sebelum pembelajaran di sekolah. Peta konsep yang dibuat nantinya membantu siswa menjelaskan suatu konsep atau materi di depan kelas sehingga membuat siswa lebih serius dalam kegiatan pembelajaran. Siswa berusaha agar memahami materi pelajaran dengan ikut berpartisipasi memecahkan permasalahan yang diberikan pada LKS dan menanyakan hal-hal yang belum dipahami kepada siswa lain. Siswa yang membantu temannya akan semakin memahami dan terlatih dalam menyampaikan suatu konsep. Selain itu, siswa yang sudah memahami konsep dengan baik tentunya dapat memberikan contoh dari suatu konsep tersebut. Hal ini sesuai dengan teori dari Firman (2000) yang menyatakan bahwa seorang siswa dikatakan telah memahami suatu konsep jika memiliki kemampuan untuk menangkap makna dari informasi yang diterima berupa:

(a) menafsirkan bagan, diagram atau grafik, (b) menerjemahkan suatu pernyataan verbal kedalam formula matematis, (c) memprediksi berdasarkan kecenderungan tertentu (interpolasi dan ekstrapolasi), (d) mengungkapkan suatu konsep dengan kata-kata sendiri. Dengan demikian, indikator pemahaman konsep terkait siswa mampu menyatakan ulang konsep dengan kata-kata sendiri dan mengidentifikasikan yang termasuk contoh dan bukan contoh dari suatu konsep dapat tercapai, (2) siswa melakukan kegiatan diskusi kelompok yang membantu siswa saling membagi informasi terkait materi maupun menyelesaikan berbagai jenis soal yang terkait dengan konsep yang sedang dipelajari sehingga melatih siswa untuk dapat menyelesaikan berbagai jenis soal. Hal ini sesuai dengan teori dari Hudojo (2005) menyatakan pemahaman terhadap bahan pelajaran dapat diperkuat bila disajikan latihan-latihan soal yang berhubungan dengan bahan yang disajikan. 
Apabila siswa sudah terampil mengerjakan latihan-latihan berarti memori siswa akan menjadi kuat. Dengan memori tersebut diharapkan siswa mampu mengaplikasikan bahan-bahan yang sudah dipelajari itu ke situasi yang lain. Dengan demikian, indikator pemahaman konsep terkait mengidentifikasikan konsep dalam berbagai situasi dapat tercapai.

Temuan pada penelitian ini sejalan dengan hasil penelitian yang telah dilakukan oleh Wahyuningsih (2013) yang menyatakan bahwa model pembelajaran Student Facilitator and Explaining dapat meningkatkan pemahaman konsep siswa kelas VIII, namun memerlukan persiapan yang agak rumit. Sukma (2015) menyatakan bahwa pemahaman konsep matematika siswa yang dibelajarkan dengan model pembelajaran Student Facilitator and Explaining lebih baik daripada siswa yang dibelajarkan dengan model pembelajaran konvensional. Astuti (2013) menyatakan selama pembelajaran dengan menggunakan model pembelajaran Student Facilitator and Explaining siswa lebih aktif, kreatif, dan berani mengeluarkan ide-ide yang dimilikinya daripada pembelajaran menggunakan model pembelajaran STAD. Selain itu, temuan di atas juga sesuai dengan teori yang diungkapkan oleh Kurniasih (2015) yang menyebutkan bahwa kelebihan dari model pembelajaran Student Facilitator and Explaining, yaitu (1) siswa diajak untuk dapat menerangkan materi pelajaran kepada siswa lain, (2) siswa bisa belajar mengeluarkan ide-ide yang ada dipikirannya sehingga lebih memahami materi tersebut.

Tanggapan masing-masing siswa terhadap model pembelajaran Student Facilitator and Explaining dalam pembelajaran matematika berada pada kriteria positif. Hal ini menunjukkan bahwa siswa dapat menerima pembelajaran dengan baik setelah diterapkannya model pembelajaran Student Facilitator and Explaining. Berdasarkan hasil angket tanggapan, pembelajaran yang diterapkan mampu membelajarkan siswa untuk aktif dan lebih memahami materi pelajaran.

\section{SIMPULAN DAN SARAN}

Berdasarkan hasil penelitian dan pembahasan yang telah dipaparkan pada bab sebelumnya, dapat disimpulkan beberapa hal sebagai berikut.

$$
\text { Peningkatan aktivitas belajar }
$$

matematika siswa kelas VIII A3 SMP Negeri 3 Sawan dapat dicapai melalui penerapan model pembelajaran Student Facilitator and Explaining dari siklus I ke siklus II dan dari siklus II ke siklus III. Peningkatan aktivitas belajar matematika siswa dapat terjadi karena (1) adanya kegiatan menjelaskan/ mendemonstrasikan suatu konsep ke depan kelas secara bergiliran sehingga siswa harus berdiskusi dengan baik agar memahami konsep-konsep yang sedang dipelajari, (2) kegiatan mengulas materi dari awal pembelajaran yang memberikan kesempatan kepada siswa untuk menanyakan hal-hal yang belum dipahami, (3) peranan siswa sebagai fasilitator dalam masing-masing kelompoknya, siswa yang malu bertanya kepada guru akan bertanya kepada siswa lain sedangkan siswa yang ditanyakan akan berusaha menjawab pertanyaan temannya, (4) kegiatan membuat peta konsep di rumah sebelum materi pelajaran disampaikan di sekolah sehingga siswa terlihat lebih siap untuk melaksanakan pembelajaran di sekolah, (5) kegiatan mencatat poin-poin penting dari materi yang sedang dipelajari dan kegiatan apersepsi di awal pembelajaran membantu siswa dalam membuat kesimpulan dari keseluruhan materi yang telah dipelajari pada suatu pertemuan, sehingga siswa mampu membuat kesimpulan di dalam kelompoknya dan berani mengacungkan tangan untuk menyampaikan kesimpulan.

Penerapan model pembelajaran Student Facilitator and Explaining dapat meningkatkan pemahaman konsep matematika siswa kelas VIII A3 SMP Negeri 3 Sawan. Peningkatan ini dapat terjadi karena (1) adanya kegiatan membuat peta konsep sebelum pembelajaran di sekolah dan menjelaskan suatu konsep atau materi di depan kelas membuat siswa berusaha memahami materi pelajaran dengan ikut berpartisipasi memecahkan permasalahan yang diberikan pada LKS serta menanyakan hal-hal yang belum 
dipahami kepada siswa lain, sedangkan siswa yang membantu temannya akan semakin paham dan terlatih dalam menyampaikan suatu konsep, (2) kegiatan diskusi membantu siswa untuk saling membagi informasi terkait materi maupun jenis-jenis soal yang berbeda sehingga melatih siswa untuk dapat menyelesaikan berbagai jenis soal, $\quad$ (3) kegiatan mengamati poin-poin penting dari materi pelajaran membantu siswa mengetahui inti dari materi yang sedang dipelajari dan konsep-konsep penting yang ditekankan sehingga memudahkan siswa untuk mengidentifikasi contoh dan bukan contoh dari suatu konsep. Selain itu, kegiatan mengulas kembali materi dari awal pembelajaran melatih siswa untuk memantapkan pemahaman siswa terhadap meteri yang telah dipelajari dengan memberikan pertanyaan pancingan barupa pertanyaan mengidentifikasi contoh dan bukan contoh untuk mengecek pemahaman siswa terhadap materi yang telah dipelajari.

$$
\text { Tanggapan siswa terhadap }
$$
penerapan model pembelajaran Student Facilitator and Explaining pada akhir siklus II dan akhir siklus III hampir sama yaitu rata-rata skor tanggapan yang diperoleh masing-masing siswa berada pada kriteria positif.

Adapun saran yang dapat disampaikan berdasarkan hasil penelitian yang telah dilakukan yaitu bagi guru matematika yang ingin mengoptimalkan aktivitas belajar dan pemahaman konsep matematika siswa, pembelajaran matematika dengan penerapkan model pembelajaran Student Facilitator and Explaining layak untuk dipertimbangkan sebagai salah satu alternatif dalam mengatasi masalah tersebut. Pembaca yang berminat untuk melaksanakan penelitian lebih lanjut mengenai penerapan model pembelajaran Student Facilitator and Explaining diharapkan agar memperhatikan kendala-kendala yang dialami selama pelaksanaan penelitian sebagai bahan pertimbangan untuk perbaikan dan penyempurnaan pelaksanaan penelitian.

\section{DAFTAR PUSTAKA}

Candiasa. 2010a. Pengujian Instrumen Penelitian Disertai Aplikasi ITEMAN dan BIGSTEPS. Singaraja: Unit Penerbitan Universitas Pendidikan Ganesha.

Candiasa. 2010b. Statistik Univariat dan Bivariat Disertai Aplikasi SPSS. Singaraja: Unit Penerbitan Universitas Pendidikan Ganesha.

Hudojo, H. 2005. Pengembangan Kurikulum dan Pembelajaran Matematika. Malang: IKIP Malang.

Kurniasih, I. dan Berlin Sani. 2015. Ragam Pengembangan Model Pembelajaran untuk Meningkatkan Profesionalisme Guru. Jakarta: Kata Pena.

Sardiman, A.M. 20011. Interaksi \& Motivasi Belajar Mengajar. Cetakan Ke-19. Jakarta: PT Raja Grafindo Persada.

Suprijono, A. 2009. Cooperative Learning Teori dan Aplikasi PAIKEM. Yogyakarta: Pustaka Pelajar.

Sukma, A. 2015. Pengaruh Model Pembelajaran Student Facilitator and Explaining dengan Strategi FIRE-UP terhadap Pemahaman Konsep Siswa Kelas VIII SMP Negeri 2 Singaraja. Skripsi (tidak diterbitkan). Jurusan Pendidikan Matematika, Universitas Pendidikan Ganesha Singaraja.

Suryani, N. dan Leo Agung. 2012. Strategi Belajar Mengajar. Yogyakarta: Ombak.

Wahyuningsih, D. 2013. Keefektifan Model Pembelajaran Student Facilitator and Explaining Berbantuan $C D$ Interaktif terhadap Minat dan Pemahaman Konsep Siswa. Skripsi (tidak diterbitkan). Jurusan Matematika, Universitas Negeri Semarang. 